\title{
PENERAPAN KONSEP ANDERSON DALAM MEMILIH MEDIA PEMBELAJARAN UNTUK GURU SMA MUHAMMADIYAH 4 SONGGON BANYUWANGI
}

\section{APPLICATION OF THE ANDERSON CONCEPT IN CHOOSING LEARNING MEDIA FOR TEACHER, SONGGON 4, MUHAMMADIYAH HIGH SCHOOL}

\author{
Agus Milu Susetyo \\ FKIP Universitas Muhammadiyah Jember \\ Email: agusmilus@unmuhjember.ac.id
}

\begin{abstract}
ABSTRAK
Semakin lama media pembelajaran yang digunakan oleh pendidikan berkembanga dengan cepat. Perantara informasi pembelajaran ini, sekarang memiliki beragam jenis serta macam-macamnya. Dahulu kita masih mengenal atau menggunakan buku cetak, radio, rekaman kaset untuk menunjang pembelajaran. akan tatapi, sekarang ini media tersebut sudah banyak ditinggalkan. Media cetak, kaset, dan radio sudah jarang digunakan. Semua media sekarang ini sudah dalam bentuk digital yang mudah dibawa, digandakan dan dioperasikan. Kenyataan ini mengakibatkan banyak penulis buku media pembelajaran memiliki beragam pendapat dalam membedakan jenis atau macam media. Tidak cukup sampai situ, tiap-tiap penulis buku tersebut menawarkan kepada pendidik dalam cara memilih media yang tepat dan yang sesuai dengan tujuan pembelajara. Hal ini akan memusingkan pendidik jika tiap penulis buku media memiliki cara sendiri-sendiri yang berbeda. Kebingungan memilih media ternyata dialami oleh guru-guru yang ada di SMA Muhammadiyah 4 Songgon Banyuwangi. Berdasarkan hasil wawancara dan observasi pelaksana PKM menemukan beberapa fakta. (a) sekolah ini tergolong masih baru, terlihat dari jumlah guru, keadaan gedung, jumlah siswa dan sarana yang dimiliki. (b) pendidik di sana masih merasa kesulitan dalam menentukan media yang cocok, karena terpaku dalam media cetak yang dimiliki sekolah yang kenyataannya justru kurang memenuhi asas kebermanfaatan. (c) kurangnya minat siswa dalam belajar ketika media yang digunakan kurang variatif. Fakta-fakta inilah yang mendorong adanya PKM. Adapun metode atau upaya dari pelaksana PKM untuk mengatasi masalah ini. Caranya adalah melaksanakan PKM dengan konsep pelatihan memilih media yang tepat dengan menggunakan diagram alur (flowchart) milik Anderson. Kegiatan ini dilakukan dengan beberapa tahap. (a) Memperkenalkan konsep dasar tentang media pembelajaran. (b) Memperkenalkan teori pemiliihan media menurut Anderson. (c) Memberikan penugasan singkat untuk memilih media sesuai dengan tujuan pembelajaran. kegiatan ini dilakukan dengan 3 tahap yaitu persiapan, pelaksanaan dan evaluasi/monitoring. Pelaksana telah melaksanakan kegiatan pada tanggal 22 November 2017 selama durasi 3 jam dengan lancara. Hasil dari kegiata ini (1) pihak sekolah SMA 4 Muhammadiyah Songon menyambut baik acara ini dan mengharapkan akan ada lagi kegiatan serupa atau beda yang tentunya dengan topik yang beragam, (2) pengetahuan guru di sekolah dan pemahaman cara memilih media pembelajaran, (3) adanya itikan baik untuk meningkatkan keterampilan guru dalam mengajar.
\end{abstract}

Kata kunci: pelatihan, media, pembelajaran, pendidik, pesert didik, diagram

\footnotetext{
ABSTRACT

The longer the learning media used by education develop rapidly. The intermediary for learning information now has a variety of types and types. In the past we still knew or used printed books, radios, cassette recordings to support learning. But, now the media has been abandoned a lot. Print media, tapes and radios are rarely used. All media are
} 
now in digital form that is easy to carry, duplicate and operate. This fact resulted in many writers of learning media books having various opinions in distinguishing types or types of media. It is not enough to go there, each author of the book offers educators in how to choose the right media and in accordance with learning objectives. This will confuse educators if each media book writer has a different way of doing it. Confusion in choosing the media was experienced by teachers in Songgon Banyuwangi 4 Muhammadiyah High School. Based on the results of interviews and observations PKM implementers found several facts. (a) this school is still new, as seen from the number of teachers, the condition of the building, the number of students and facilities owned. (b) educators there still find it difficult to determine suitable media, because fixation in print media owned by schools in fact actually does not fulfill the principle of usefulness. (c) lack of student interest in learning when the media used is less varied. These facts encourage the PKM. The method or effort of PKM implementers to overcome this problem. The trick is to implement PKM with the training concept of choosing the right media using Anderson's flowchart. This activity is carried out in several stages. (a) Introducing the basic concepts of learning media. (b) Introducing the theory of media selection according to Anderson. (c) Provide short assignments to select media according to the learning objectives. this activity was carried out in 3 stages namely preparation, implementation and evaluation / monitoring. The executor has carried out activities on November 22, 2017 for a duration of 3 hours in a smooth manner. The results of this activity (1) the Muhammadiyah Songon High School 4 welcomed the event and hoped there would be more similar or different activities with diverse topics, (2) teacher knowledge in schools and understanding how to choose learning media, (3) the existence of good ducks to improve teacher skills in teaching.

Keywords: training, media, learning, educators, students, diagrams

\section{PENDAHULUAN}

Perkembangan jaman sangalah cepat sekarang ini. Dahulu seseorang lapar harus pergi ke warung atau restoran untuk mengisi perutnya, tetapi sekarang bisa mengandalkan smart phone makanan yang diinginkan akan datang ke rumah pemesan. Belum lagi media hiburan, dahulu jika ingin melihat tontotan atau acara tv, seseorang hanya bisa melihatnya dengan menonton tv. Namun, sekarang jauh berbeda, jaringan internet, smart phone, smart $t v$, sudah bisa digunakan untuk melihat hiburan layaknya acara di tv. Ini merupakan beberapa contoh kemajuan IPTEK. Perkembangan IPTEK mau tidak mau harus bisa semakin mendorong upaya pembaharuan dalam pemanfaatan hasil perkembangan IPTEK dalam proses pembelajaran. Guru semakin dituntut untuk menggunakan media pembelajaran yang disediakan sekolah. Tidak jarang sekolah telah menyediakan media yang sangat beragam. Mulai dari media yang lama, tradisonal sampai media yang sangat modern sebagai hasil dari kemajuan jaman. Bahkan tidak menutup kemungkinan ada sekolah yang menyediakan media pembelajaran sesuai dengan kemajuan zaman. 
Seorang guru harus bisa memanfaatkan media pembelajaran untuk menunjang proses pembelajaran. ketercapain tujuan pengajaran merupakan harga mati yang harus dipenuhi untuk mencapai keberhasilan. Se'mentara itu keberhasilan pembelajaran ditunjang dengan adanya media pembelajaran yang sesuai. Hal ini didukung oleh pendapat Hamalik (1986) yang dikutip Azhar Arsyad (2010: 15), mengemukakan bahwa pemakaian media pembelajaran dalam proses belajar mengajar dapat membangkitkan keinginan dan minat yang baru, membangkitkan motivasi dan rangsangan kegiatan belajar, dan membawa pengaruh-pengaruh psikologis terhadap siswa.

Pertanyaan mendasar atas latar belakang tersebut adalah sudahkah guru menggunakan media pembelajaran yang tepat? Pertanyaan ini hanya bisa dijawab jika guru pandai memilih media yang tepat sesuai dengan kompetensi yang dicapai siswa. Proses memilih media pun sejatinya sudah dilakukan oleh guru saat membuat RPP. Akan tetapi RPP yang dibuat guru dibuat dengan terburu-buru bahkan ada yang hanya mengunduh dari internet. Kejadian ini tentunya tidak dibenarkan. Media yang merupakan unsur pembangun dari RPP harusnya dipilih dengan teliti karena media sangat menunjang proses belajar mengajar. Tidak hanya itu, peran media masih banyak kegunaannya dalam pembelajaran.

Perubahan kurikulum tidak dapat dipungkiri harus ditanggapi positif oleh guru. Bagaimana tidak karena perkembangan jaman, termasuk IPTEK harus dibarengi dengan SDM yang handal. Mulai dari siswa yang dikembangkan sesuai perubahan zaman hingga guru yang profesional dan mampu beradaptasi dengan perubahan ini. jika ini dilakukan mana Indonesia akan dapat bersaing dengan negara lain khususnya bidang pendidikan. Kenyataan terbalik terjadi adalah salah satu sekolah SMA yang tergolong baru, yaitu Muhammadiyah 4 Songgon Banyuwangi. Di tempat ini, memiliki guru yang masih bingung atau kurang tepat ketika memilih media pembelajaran yang sesuai dengan tujuan pembelajaran. akibatnya siswa menjadi tidak memahami pelajaran yang dipelajari atau dipaparkan oleh gurunya sehingga adanya indikasi turunnya minat belajar.

Berdasarkan kenyataan tersebut diagram alur (flowchart) milik Anderson harus dihadirkan dan dipelajari oleh pendidik SMA Muhammadiyah 4 Songgon Banyuwangi. Oleh karena itu dilakukan sebuah kegiatan pengapdian kepada masyarakat atau PKM. Konsep yang dipakai dalam kegiatan ini adalah dengan bentuk pelatihan. Pengabdian ini digunakan untuk guru pelajaran yaitu memberikan trik atau solusi cepat dalam memilih 
media pembelajaran yang sesuai dengan tujuan pembelajaran. media yang tepat akan menunjang proses pembelajaran sehingga tidak membuang kegiatan yang sia-sia. Selain itu membuat siswa semakin bersemangat untuk belajar.

\section{METODE PELAKSANAAN}

Berdasarkan target dan luaran yang diusulkan dalam kegiatan Program Kemitraan Masyarakat (PKM) ini maka diuraikan tahapan dalam mencapai target dan menghasilkan luaran kegiatan produksi ditunjukkan dalam Tabel di bawah ini.

Tabel Tahapan Kegiatan Pelatihan

\begin{tabular}{|c|c|c|}
\hline Solusi & Luaran & Tahapan \\
\hline \multirow{3}{*}{$\begin{array}{l}\text { Penerapan } \\
\text { Konsep } \\
\text { (Diagram Alur) } \\
\text { Anderson } \\
\text { Dalam Memilih } \\
\text { Media } \\
\text { Pembelajaran }\end{array}$} & $\begin{array}{ll}\text { Buku } & \text { panduan } \\
\text { dalam } & \text { memilih } \\
\text { media } & \end{array}$ & $\begin{array}{l}\text { 1. Melakukan kegiatan studi pustaka untuk } \\
\text { memperoleh referensi yang berkaitan dengan } \\
\text { permasalahan. } \\
\text { 2. Penyediaan perangkat penunjang oleh } \\
\text { pelaksana PKM yaitu, PPT, Hand Book, } \\
\text { lembar tugas. }\end{array}$ \\
\hline & $\begin{array}{l}\text { Perjanjian kerja } \\
\text { sama }\end{array}$ & $\begin{array}{l}\text { 1. Melakukan pertemuan dengan pihak SMA } \\
\text { Muhammadiyah 4 Songgon untuk } \\
\text { menawarkan solusi. } \\
\text { 2. Penentuan waktu pelaksanaan kegiatan } \\
\text { pengabdian bersama tim pelaksana dan } \\
\text { khalayak target. } \\
\text { 3. Surat pengantar kegiatan PKM dari LPPM } \\
\text { kampus Universitas Muhammdiyah Jember }\end{array}$ \\
\hline & $\begin{array}{l}\text { Pengetahuan, dan } \\
\text { keterampilan } \\
\text { Memilih media } \\
\text { pembelajaran }\end{array}$ & $\begin{array}{l}\text { 1. Pemaparan Materi } \\
\text { 2. Tanya jawab } \\
\text { 3. Pemberian tugas latihan }\end{array}$ \\
\hline
\end{tabular}

Dalam Penerapan Konsep (Diagram Alur) Anderson Dalam Memilih Media

Pembelajaran, Tim Pengusul bertindak sebagai pemberi materi, pembimbing dan evaluator. Sebagai pemberi materi, pelaksana PKM menyampaikan mater dalam bentuk ceramah dan tanya jawab serta penugasan. Sebagai pembimbing disini maksudnya adalah ketika audien bertanya dan saat mengerjakan tugas, pelaksana PKM memberikan jawaban dan bantuan kepada audien. Sebagai evaluasitor, maksudnya adalanya pelaksana PKM melakukan penilaian dan pengmbilan keputusan akhir setelah kegiatan selasai, apakah konsep yang diberikan dapat dipahami atau tidak. Pelaksana PKM dibantu dengan beberapa perangkat pendukung ketika memberikan materi yaitu (a) buku manual, (b) ppt, (c) lembar tugas, (d) lembar absensi, (e) lcd proyektor dan laptop. 


\section{Teknik Pengumpulan Data}

Data dalam kegiatan pengapdian ini adalah berupa hasil jawaban audien terkait materi yang telah dipelajari. Jadi teknik yang dipakai adalah tes. Tujuan dari teknik ini adalah untuk mengetahui kemampuan atau keterampilan audiens dalam menentukn jenis media yang tepat sesuai dengan KD dan tujuan pembelajaran.

\section{Teknik Analisis Data}

Pelaksana PKM melakukan analisis data dengan beberapa tahapan yaitu, (a) reduksi, (b) penyajian data dan (c) penarikan kesimpulan. Berikut ini pemaparan langkah-langah dalam teknik analisisnya.

a. Reduksi data merupakan proses seleksi, pemfokusan, penyederhanaan data. Proses ini berlangsung terus sepanjang kegiatan. Reduksi data dalam kegiatan ini berupa penyeleksian data-data yang diperoleh dari sumber yang ada. Penyeleksian ini difokuskan lembar jawaban dari audien yang masih layak dijadikan sumber data.

b. Penyajian data, pada langkah ini peneliti memaparkan data yang telah direduksi, dipaparkan dengan dalam bentuk deskripsi. Pelaksana kegiatan melajutkan penyajian dengan menafsirkan semua hasil data-datanya untuk dipertanggung jawabkan sesuai permasalahan yang telah dirumuskan.

c. Tahap akhir, pada tahap ini, peneliti melakukan penyimpulan terhadap data yang telah dipaparkan sesuai teori yang digunakan. Penyimpulan dilakukan secara deskriptif kualitatif dengan bahasa yang baik dan benar, singkat, padat, dan mudah dipahami.

\section{Lokasi, waktu, dan durasi kegiatan}

Lokasi kegiatan PKM dilaksanakan di SMA Muhammadiyah 4 Songgon dengan durasi kurang lebih 2-3 jam. Kegiatan ini dilaksanana sesuai dengan kesepaakatan yaitu pada tanggal 22 November 2017. Pemilihan waktu dan durasi kegiatan PKM telah didiskusikan antara pihak pelaksanan PKM dan pihak sekolah.

\section{HASIL KEGIATAN}

Dalam Program Kemitraan Masyarakat (PKM) ini telah dilakukan serangkaian kegiatan meliputi persiapan, pelaksanaan dan evaluasi. Berikut pemaparannya. 


\section{Kegiatan Persiapan}

Tahap ini dilakukan dengan beberapa kegiatan diantaranya sebagai berikut.

a. Melakukan observasi di sekolah untuk memastikan kebutuhan apa yang urgen ditempat PKM.

b. Menyusun proposal kegiatan PKM untuk mendapatkan persetujuan dan dukungan materi di LPPM kampus universitas muhammadiyah jember.

c. Menyampaikan kembali kepada pihak sekolah tentang alur kegiatan dan menyerahkan surat pengantar dari kampus.

d. Mengadakan perjanjian terkait jadwal, metode, tempat, audiens, dll untuk memperlancar kegiatan nantinya.

e. Pelaksanan menyusun media presentasi, buku panduan dan sarana pendukung lainnya.

Berikut ini beberapa gambar sarana pendukung yang disiapkan pelaksanan PKM dengan tujuan agar kegiatan berjalan dengan lancar.

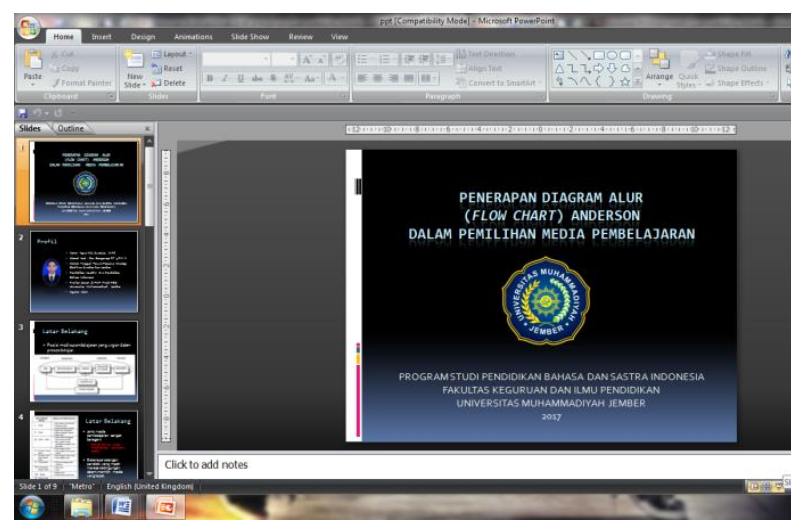

Gambar 1. Power Point materi PKM

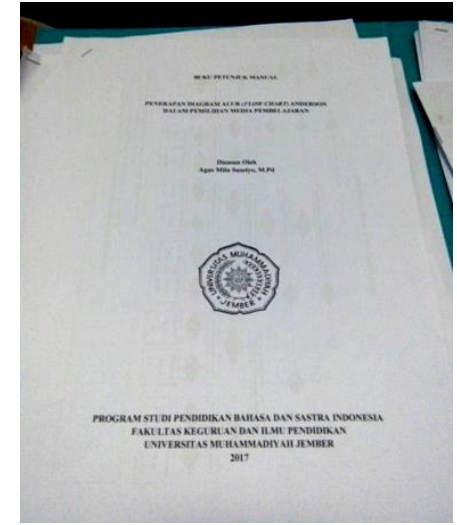

Gambar 2 Buku panduan materi PKM 

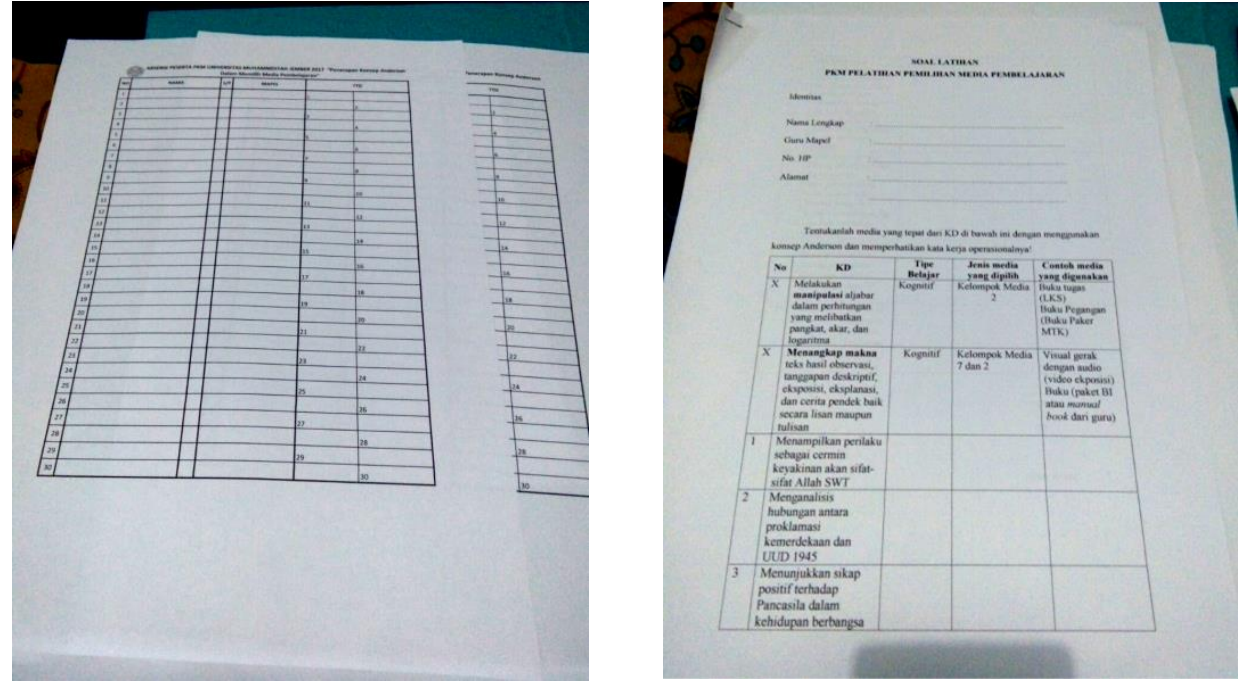

Gambar 3 Lembar absensi kegiatan PKM Gambar 4 Lembar soal latihan untuk audiens
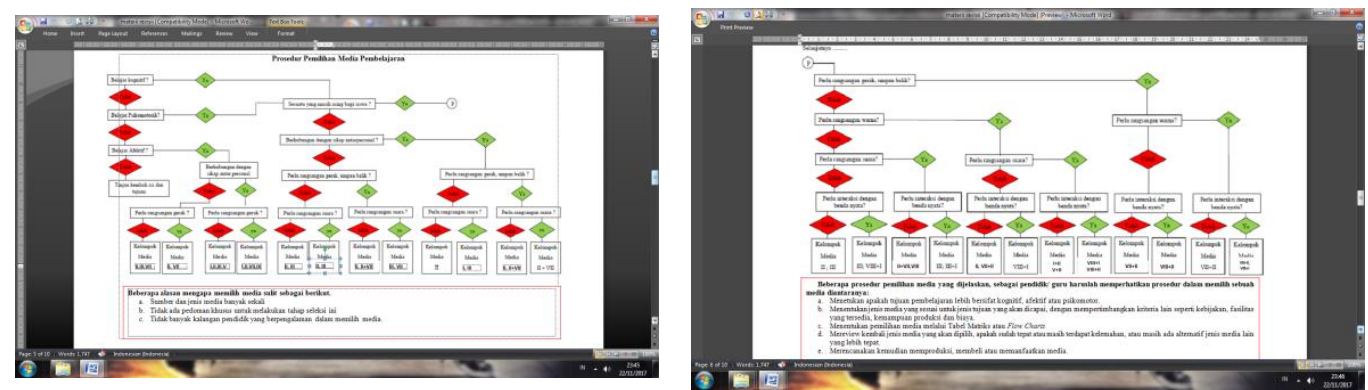

Gambar 5 diagram alur Anderson

\section{Tahap pelaksanaan}

Tahap pelaksanaan PKM dilakukan dengan tata cara pelatihan atau seminar pada umumnya. Kegiatan PKM di awai dengan sambutan dari Kepala Sekolah, lalu pemateri, tanya jawab dan terakhir adalah penutup. Durasi kegiatan ini sekitar 3 jam, dimulai dari pukul 10:00 sampai 13:00 WIB. Pelaksana PKM menggunakan perantara dengan Bahasa Indonesia yang komunikatif. Berikut ini rincikan kegiatannya.

a. Pelaksana membuka kegiatan dengan perkenalan setelah sambutan dari kepala sekolah.

b. Pelaksana memaparkan materi yang telah dipilih dan dibarengi dengan sesi tanya jawab dengan audiens.

Berikut ini beberapa bukti dokumentasi dari kegiatan yang telah dikasanakan. 

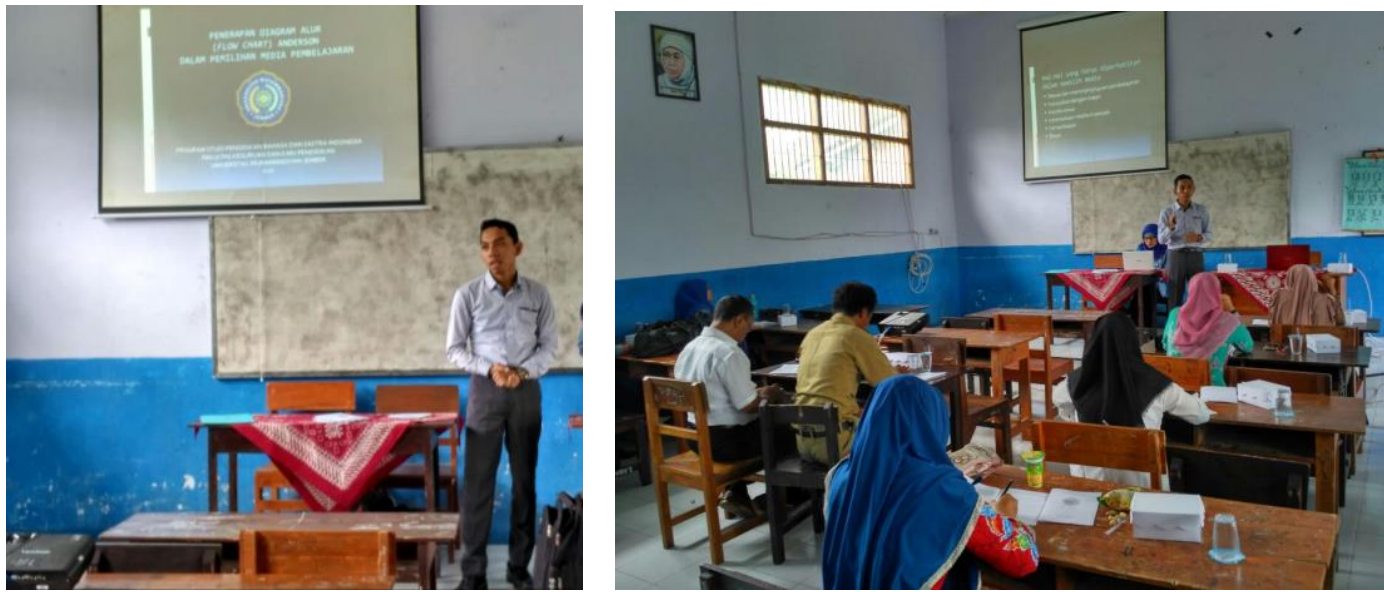

Gambar 6 Pelaksana PKM memperkenalkan diri dan memberikan materi

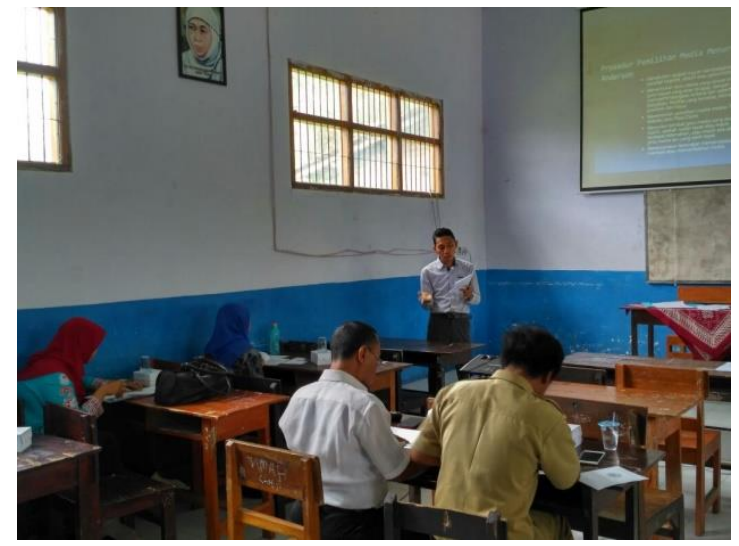

Gambar 7 Pelaksana PKM menjawab pertanyaan audiens

\section{Tahap Monitoring dan Evaluasi}

Tahap monitoring dan evalasi dilakukan dengan cara pemberian tugas. Evaluasi yang diberikan berupa bentuk tugas yaitu memberikan lembaran tugas berupa soal yang berhubungan dengan media pembalajaran. Tugas peserta PKM adalah menentukan media yang tepat sesuai dengan KD dan kondisi siswa dan sekolah.

\section{KESIMPULAN DAN SARAN}

Kesimpulan yang dapat diambil dari kegiatan PKM tentang Penerapan Konsep (Diagram Alur) Anderson Dalam Memilih Media Pembelajaran sebagai berikut. (1) Pihak sekolah SMA 4 Muhammadiyah Songon menyambut baik acara ini dan mengharapkan akan ada lagi kegiatan serupa atau beda yang tentunya dengan topik yang beragam. (2) Pengetahuan guru di sekolah dan pemahaman cara memilih media pembelajaran. (3) Adanya itikad baik untuk meningkatkan keterampilan guru dalam mengajar. Saran yang bisa diberikan sebagai berikut. (a) 
Kegiatan serupa hendaknya dimulai lebih pagi untuk mendapatkan kondisi audien yang lebih fresh dan lengkap. (b) Hendaknya koordinasi dengan pihak sekolah dilakukan jauh-jauh hari untuk memperoleh audiens yang lebih lengkap.

\section{DAFTAR PUSTAKA}

Arsyad, Azhar. 2005. Media Pembelajaran. Jakarta: Grafindo Persada.

Asnawir dan M. Basyiruddin Usma. 2002. Media Pembelajaran . Jakarta: Ciputat Pers.

Departemen Pendidikan dan Kebudayaan. 2002. Kamus Besar Bahasa Indonesia, Jakarta: Balai Pustaka.

Djamarah, Syaiful Bahri dan Aswan Zain. 2006. Strategi belajar Mengajar. Jakarta: Rineka Cipta.

Ibrahim, H., Sihkabuden, Suprijanta, \& Kustiawan, U. 2001. Media pembelajaran: Bahan sajian program pendidikan akta mengajar. FIP. UM.

Muhaimin. 2002. Paradigma Pendidikan Islam Upaya Mengefektifkan Pendidikan Agama Islam Di Sekolah. Bandung: Remaja Rosda karya.

M. Suyanto.2003. Multimedia Alat Untuk Meningkatkan Keunggulan bersaing. Yogyakarta: Penerbit Andi.

Nurkholis, Ahmad. 2012. Pentingnya Media dalam Pembelajara, (from: http://ahmadnurkholis19.blogspot.com/2012/12/pentingnya-media-dalampembelajaran-pai.html.) diaksestanggal 18 Oktober 2013.

Sadiman, A.S. 1986. Media Pendidikan: Pengeratian, Pengembangan, dan Pemanfaatannya. Jakarta: Cv. Rajawali.

Sihkabuden. 1994. Klasifikasi dan Karakteristik Media Instruksional Sederhana. Malang: FIP IKIP Malang.

Yonathanloka, Christian. 2013. Pemilihan dan Pengembangan Media Pembelajaran. (from:http://christianyonathanlokas.wordpress.com/2013/10/09/pemilihan-danpengembangan-media pembelajaran/). Diakses tanggal 2 Mei 2014. 